\title{
Desain dan Studi In Silico Senyawa Turunan Kuwanon-H sebagai Kandidat Obat Anti-HIV
}

\section{Design and In Silico Study of Kuwanon-H as Anti-HIV Drug Candidate}

\author{
Ruswanto $^{1,}$ Tita Nofianti ${ }^{1}$, Richa Mardianingrum ${ }^{2}$, Tresna Lestari $^{1}$, Ardelia Sepriliani ${ }^{1}$ \\ ${ }^{1}$ Prodi Farmasi, STIKes Bakti Tunas Husada, Tasikmalaya 46115, Indonesia \\ ${ }^{2}$ Prodi Farmasi, Universitas Perjuangan, Tasikmalaya 46115, Indonesia
}

Email: ruswanto@stikes-bth.ac.id

\begin{abstract}
Abstrak
Kuwanon-H merupakan senyawa flavonoid dari kulit akar murbei (Morus alba $\mathrm{L}$ ) yang secara in vitro berpotensi sebagai anti-HIV dibanding senyawa flavonoid lainnya yang terkandung dalam kulit akar murbei seperti morusin dan morusin 4'-glukosida. Telah dilakukan penelitian desain senyawa, penambatan molekular menggunakan ArgusLab 4.0.1 dengan metode ArgusDock, penerapan aturan Lipinski's Rule of Five menggunakan Marvin Sketch 5.2.5.1dan uji toksisitas menggunakan aplikasi Toxtree secara in silico terhadap turunan senyawa kuwanon-H. Desain enam puluh senyawa turunan kuwanon-H dilakukan dengan cara model pendekatan Topliss pada rantai samping alifatiknya. Hasil penambatan ke-60 turunan senyawa pada reseptor HIV-1 Reverse Transcriptase (1REV) menunjukkan bahwa senyawa terbaik yaitu 3-[(2Z)-3-(siklopropilmetil)but-2-en-1-il]-8-[6(\{3-[(2Z)-3-(siklopropilmetil)but-2-en-1-il]-2,4-dihidroksifenil $\}$ carbonil)-5-(2,4-dihidroksilfenil)-3-metilsikloheks2-en-1-il]-2-(2,4-dihidroksifenil),7-dihhidroksi-4H-kromen-4-on dengan nilai energi bebas yang lebih rendah $(-12.5798 \mathrm{kkal} / \mathrm{mol})$ dibandingkan ligan asli $(-11.0445 \mathrm{kkal} / \mathrm{mol})$ dan kuwanon-H $(-11.0189 \mathrm{kkal} / \mathrm{mol})$. Senyawa terbaik ini tidak memenuhi aturan Lipinski's Rule of Five. Hasil prediksi uji toksisitas senyawa terbaik menurut parameter Cramer Rules termasuk kategori III, yaitu diprediksi memiliki toksisitas tinggi, menurut parameter Benigni/Bossa Rulebase diprediksi senyawa yang diuji tidak bersifat karsinogenik, genotoksik, dan nongenotoksik, sedangkan menurut parameter Kroes TTC decision tree diprediksi senyawa uji berpotensi toksik.
\end{abstract}

Kata kunci: Anti HIV-1 Reverse Transcriptase , in silico, Kuwanon-H.

\begin{abstract}
Kuwanon-H is a flavonoid compound from the root bark of the mulberry (Morus alba $\mathrm{L}$ ) which is potentially acts as an anti-HIV. We have performed molecular docking using ArgusLab 4.0.1 with ArgusDock method, the application of Lipinski's Rule of Five using MarvinSketch 5.2.5.1 and toxicity prediction test has been performed by Toxtree for Kuwanon-H derivatives compound. The sixty of kuwanon- $\mathrm{H}$ derivatives compound were done by Topliss model in an aliphatic side chain. From the molecular docking results were showed that the best interaction with HIV-1 Reverse Transcriptase receptor (1REV) namely the 3-[(2Z)-3-(cyclopropylmethyl)but-2en-1-yl]-8-[6-(\{3-[(2Z)-3-(cyclopropylmethyl) but-2-en-1-yl]-2,4-dihydroxyphenyl $\}$ carbonyl)-5-(2,4-dihydroxy phenyl)-3-methyl cyclohex-2-en-1-yl]-2-(2,4-dihydroxyphenyl),7-dihydroxy-4H-chromen-4-one compound with free energy $(-12.5798 \mathrm{kcal} / \mathrm{mol})$ and it was lower than native ligand $(-11.0445 \mathrm{kcal} / \mathrm{mol})$ and kuwanon-H $(-11.0189 \mathrm{kcal} / \mathrm{mol})$. The best compound was not qualified Lipinski's Rule of Five. According to the parameters cramer rules in the third category, it was predicted has of its high toxicity, according to the Benigni/Bossa Rulebase, it was predicted negative for genotoxic and nongenotoxic carcinogenicity, according to the Kroes TTC decision Tree parameters, it was predicted to be potentially toxic.
\end{abstract}

Keyword : Anti HIV-1 Reverse Transcriptase, in silico, Kuwanon-H

DOI: http://dx.doi.org/10.15408/jkv.v4i1.6867 


\section{PENDAHULUAN}

Pada tahun 2016, 1 juta orang meninggal karena penyebab HIV secara global. Ada sekitar 36.7 juta orang yang hidup dengan HIV pada akhir 2016 dengan 1,8 juta orang menjadi baru terinfeksi pada tahun 2016 secara global. Sebanyak $54 \%$ orang dewasa dan $43 \%$ anak-anak yang hidup dengan HIV saat ini menerima terapi antiretroviral (ART) seumur hidup (WHO, 2016).

Adanya terapi antiretrovirus yang tidak efektif mengakibatkan munculnya resistensi terhadap virus. Reverse Trancriptase HIV yang secara alami akan mendorong terjadinya evolusi keragaman genetik yang cepat serta kecenderungan berkembangnya resistensi terhadap obat antiretrovirus (Stephen dan Ghilman, 2012). Oleh karena itu, penemuan dan pengembangan senyawa baru anti HIV dengan modifkasi molekul telah banyak dilakukan sampai sekarang dengan target berbagai enzim virus HIV terutama enzim vital untuk reproduksi virus seperti Reverse Transcriptase, integrase, dan protease (Callies et al., 2015; Feng et al., 2009; Gu et al., 2015; Imai et al., 2011; Vijayakumar et al., 2017).

Salah satu upaya penemuan senyawa obat anti HIV diantaranya, Shi De et al. (1995) telah melakukan pengujian anti-HIV dari kulit akar murbei (M. Alba). Terdapat tiga senyawa yang menunjukkan aktivitas sebagai anti-HIV secara in vitro yaitu senyawa morusin, kuwanon-H dan morusin 4'-glukosida dengan kuwanon-H yang memiliki nilai $\mathrm{IC}_{50}$ terendah yaitu $1.34 \mu \mathrm{g} / \mathrm{mL}$ dibanding dengan morusin $(8.18 \mu \mathrm{g} / \mathrm{mL})$ dan morusin 4'-glukosida (2.29 $\mu \mathrm{g} / \mathrm{mL})$. Dalam basis data tanaman obat juga telah informasikan bahwa buah merah Papua yang dipercaya dapat menghambat HIV (AIDS) (Parikesit et al., 2017).

Langkah awal dalam upaya merancang dan mengembangkan obat baru sebagai antiHIV ini yaitu dengan mengembangkan kandidat obat yang telah ada dan yang sudah diketahui aktivitas biologisnya untuk dijadikan sebagai senyawa penuntun (Firdayani, 2012). Salah satunya yaitu pendekatan secara in silico seperti penambatan molekul (Ruswanto, 2015). Pendekatan ini dipilih karena memiliki keuntungan tersendiri dibandingkan pendekatan in vivo maupun in vitro, antara lain hanya membutuhkan waktu yang cepat dan biaya yang lebih murah (Ekins et al., 2002).

Tujuan penelitian ini adalah untuk menerapkan Lipinski's Rule of Five yaitu untuk membedakan antara molekul drug-like dan non drug-like dengan memperhatikan tingkat absorpsi terhadap lipid bilayer yang terdapat di dalam tubuh manusia dan uji toksisitas secara in silico sehingga sebagai salah satu pengembangan perancangan obat dapat ditemukan senyawa baru yang diharapkan mempunyai aktivitas anti-HIV lebih baik daripada senyawa pada penelitian-penelitian sebelumnya dan diketahui juga mengenai toksisitasnya.

\section{METODE PENELITIAN}

\section{Alat dan Bahan}

Peralatan yang digunakan berupa perangkat keras dan lunak komputer. Perangkat tersebut berupa personal komputer dengan spesifikasi RAM 2048MB, Intel(R) Core(TM) i3-2328M CPU @ 2.20GHz (4 CPUs), 2.2GHz system windows 7 Ultimate Service Pack 1 dan perangkat lunak berupa ArgusLab 4.0.1, MarvinSketch 5.2.5.1., Molecular Operating Environment (MOE), Molegro Molecular Viewer (MMV) dan ToxTree.

Bahan yang digunakan dalam penelitian ini yaitu reseptor HIV-1 Reverse Transcriptase (1REV) (Ren et al., 1995) dan struktur senyawa kuwanon-H serta turunannya sebanyak 60 senyawa.

\section{Preparasi Ligan Kuwanon-H dan Turunannya}

Ligan digambar menggunakan software MarvinSketch kemudian dilakukan optimasi geometri dengan melakukan protonasi pada $\mathrm{pH}$ 7,4. Selanjutnya dilakukan Conformational search (Ruswanto et al., 2015; Ruswanto et al., 2017). Prosedur di atas dilakukan untuk setiap ligan turunan kuwanon- $\mathrm{H}$ dan disimpan dengan format mol2. Preparasi ligan dilakukan dengan optimasi geometri pada struktur yang terbentuk untuk memperoleh konformasi molekul yang stabil dan memiliki energi potensial rendah yang disesuaikan dengan kondisi tubuh.

\section{Preparasi Reseptor}

Reseptor HIV-1 Reverse Transcriptase diunduh dari Protein Data Bank (PDB) dengan kode 1REV dan disimpan dalam format pdb. Kemudian dilakukan preparasi yaitu pemisahan dari ligan alaminya, penghapusan molekul pelarut dan penambahan hidrogen (Syahdi et al., 2012). 


\section{Validasi Metode Penambatan}

Validasi metode penambatan menggunakan ArgusLab 4.0.1. dengan 4chloro-8-methyl-7-(3-methyl-but-2-enyl)6,7,8,9-tetrahydro-2h-2,7,9a-tri-azabenzo[cd]azulene-1-thione (TB9) sebagai native ligan (pembanding) sedangkan ligan copy ditambatkan pada reseptor 1REV. Pada ArgusLab terdapat 2 metode yang dapat digunakan untuk penambatan yaitu ArgusDock dan GADock sehingga validasi dilakukan pada kedua metode tersebut (Thompson, 2004; Hafeez et al., 2013). Penambatan molekul dilakukan menggunakan ArgusLab karena dalam prosesnya aplikasi ini sangat mudah, cepat dan telah banyak digunakan untuk proses penambatan molekul. Metode penambatan molekul dikatakan baik jika nilai RMSD (Root Mean Square Deviation) ligan dengan ligan copy lebih kecil atau sama dengan dua (Kartasasmita et al., 2009).

\section{Desain Senyawa Turunan Kuwanon-H}

Desain senyawa dilakukan pada struktur kuwanon-H sebagai struktur induknya menggunakan modifikasi struktur model pendekatan Topliss, dengan memodifikasi 60 senyawa pada rantai samping alifatiknya. Penentuan posisi pemasukkan substituen pada struktur senyawa induk berdasarkan hasil optimasi hasil penambatan molekul dengan menggunakan metode yang valid. Posisi dengan nilai energi bebas $(\Delta \mathrm{G})$ terendah inilah yang selanjutnya digunakan untuk modifikasi senyawa induk lainnya.

\section{Penambatan Ligan Uji Terhadap Reseptor}

Ligan uji dan protein yang telah dipreparasi kemudian dilakukan penambatan mengunakan metode yang valid dengan langkah yang sama seperti pada tahap validasi penambatan namun tanpa dilakukan copy ligan, melainkan memasukkan ligan yang akan diuji. Dari hasil penambatan diperoleh nilai energi bebas $(\Delta \mathrm{G})$ senyawa uji yang kemudian dibandingkan dengan $\Delta \mathrm{G}$ native ligan.

\section{Visualisasi dan Analisis Hasil Penambatan}

Hasil penambatan kemudian divisualisasi menggunakan software Molecular Operating Environment (MOE) dalam bentuk 2 Dimensi dan Molegro Molecular Viewer (MMV) dalam bentuk 3 Dimensi dan dianalisis interaksinya.

\section{Screening Ligand Based Drug Likeness (Drug Scan)}

Pengamatan obat dilakukan pada senyawa kuwanon-H dan turunannya yang memiliki energi bebas lebih rendah dari energi bebas native ligan. Analisis pengamatan obat dilakukan dengan mempertimbangkan aturan Lipinski's rule of five. Parameter aturan ini dapat ditentukan dengan software MarvinSketch (Tambunan et al., 2012; Athar et al., 2017; Choy et al., 2011).

\section{Uji Toksisitas}

Uji toksisitas dilakukan terhadap senyawa kuwanon-H dan turunannya yang memiliki energi bebas lebih rendah dari energi bebas native ligan menggunakan software ToxTree. Parameter yang dilihat pada uji toksisitas ini adalah prediksi parameter Cramer Rules, Benigni/Bossa rulebase, dan Kroes TTC decision tree (Tambunan et al., 2012; Patlewicz et al., 2008; Contrera, 2013; Bhatarai et al., 2016; Bhatia et al., 2015).

\section{HASIL DAN PEMBAHASAN}

Di bawah ini adalah stuktur reseptor berupa enzim HIV-1 reverse transcriptase yang digunakan sebagai target dalam penelitian dan inhibitornya berupa ligan TB9 (4-chloro-8methyl-7-(3-methyl-but-2-enyl)-6,7,8,9tetrahydro-2h-2,7,9a-triaza-enzo[cd]azulene-1thione).

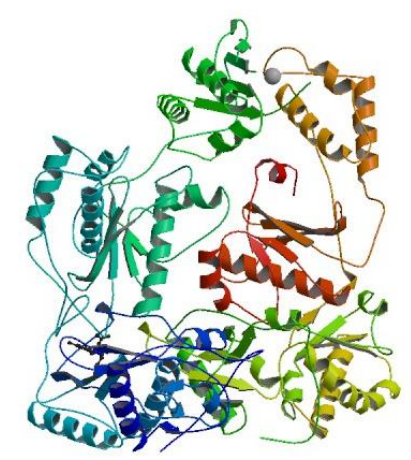

Gambar 1. Reseptor HIV-1 RT dengan liganTB9

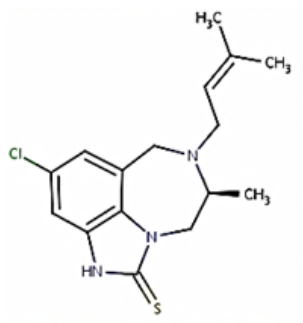

Gambar 2. Struktur ligan TB9 


\section{Hasil Validasi Metode Penambatan}

Validasi metode penambatan dilakukan dengan cara me-repenambatan kembali native ligan pada reseptor $H I V-1$ reverse transcriptase. Validasi ini bertujuan untuk mengetahui apakah reseptor yang diunduh dari PDB dapat digunakan kembali untuk penambatan senyawa turunan kuwanon-H yang diujikan. Sebelum penambatan, binding site bounding box perlu diatur sedemikian rupa sehingga ligan dan reseptor dapat berinteraksi dan menghasilkan nilai energi bebas $(\Delta G)$. Binding site bounding box diatur pada 37.25 (x), 39.50 (y) dan 44.75 (z). Binding site dari reseptor HIV-1 Reverse Transcriptase (IREV) berupa residu asam-asam amino yang berada pada jarak $5 \AA$ dari native ligand yaitu Gly A190, His A235, Ile A180, Leu A100, Leu A234, Lys A101, Lys A103, Phe A227, Pro A95, Pro A236, Tyr A181, Tyr A188, Tyr A318, Val A106, Val A179, Val A189, dan Trp A229. Karena pada ArgusLab terdapat 2 penambatan engine yang dapat digunakan untuk penambatan yaitu ArgusDock dan GADock maka validasi dilakukan pada kedua penambatan engine tersebut. Pemilihan metode ditentukan oleh nilai RMSD (Root Mean Square Deviation) antara native ligan dengan ligan copy.

Hasil validasi dengan metode ArgusDock menunjukkan nilai RMSD kurang dari $2.0 \AA$ yaitu $1.942 \AA$. Perbandingan konformasi struktur ligan TB9 dengan ligan TB9 copy hasil simulasi penambatan tersebut dapat dilihat pada Gambar 3. Sedangkan hasil validasi dengan metode GADock menunjukkan nilai RMSD lebih dari $2.0 \AA$ yaitu $15.717 \AA$. Berdasarkan hasil tersebut maka metode penambatan yang valid adalah ArgusDock.

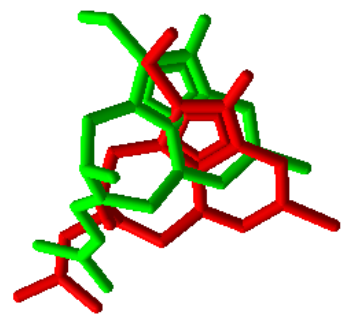

Gambar 3. Perbandingan konformasi struktur ligan TB9 (hijau) dengan ligan TB9 copy hasil simulasi penambatan dengan metode ArgusDock (merah).
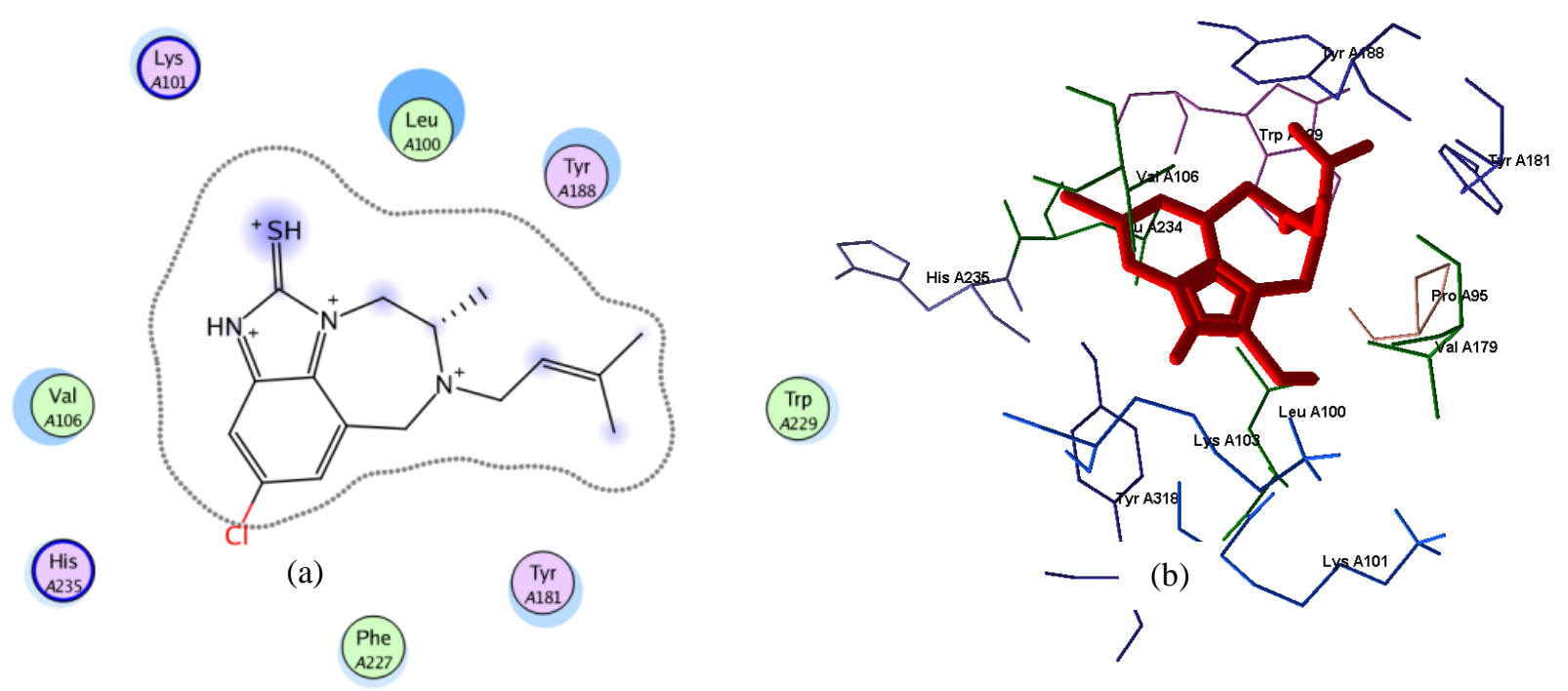

Gambar 4. (a) Visualisasi 2D interaksi penambatan pada simulasi penambatan dengan reseptor HIV-1 RT (1REV) menggunakan Molecular Operating Environment; (b) Visusalisasi 3D interaksi penambatan simulasi penambatan dengan reseptor 1REV menggunakan Molegro Molecular Viewer

\section{Desain Senyawa Turunan Kuwanon-H}

Terdapat 5 posisi yang memungkinkan adanya modifikasi struktur pada rantai samping alifatik senyawa induk yang dapat dilihat pada Gambar 5. Berdasarkan hasil penambatan, posisi substituen untuk modifikasi struktur senyawa induk yaitu pada posisi $\mathrm{X}_{1}$ dan $\mathrm{X}_{4}$ dengan nilai energi bebas yang rendah dibanding dengan posisi lainnya yaitu -10.0014 $\mathrm{kkal} / \mathrm{mol}$ dan $-10.9701 \mathrm{kkal} / \mathrm{mol}$. Pada penelitian, desain senyawa turunan kuwanon- $\mathrm{H}$ ini dilakukan pada posisi $\mathrm{X}_{1}, \mathrm{X}_{4}$ dan kedua posisi tersebut. 
<smiles>[Y]C([X])=CCc1c(O)ccc(C(=O)C2C(c3c(O)cc(O)c4c(=O)c(CC=C([Y4])[Y4])c(-c5ccc(O)cc5O)oc34)C=C([Y])CC2c2ccc(O)cc2O)c1O</smiles>

Gambar 5. Kuwanon $H, X_{1}, X_{2}, X_{3}, X_{4}, X_{5}$ adalah substituen (Marvin Sketch)

\section{Visualisasi dan Analisa Hasil Penambatan}

Nilai energi bebas $(\Delta \mathrm{G})$ ligan uji hasil penambatan antara ligan uji dengan reseptor $H I V-1 R T$ (1REV) yang diperoleh dibandingkan dengan $\Delta G$ native ligan. Semakin kecil nilai energi bebas maka semakin tinggi afinitas ligan tersebut terhadap reseptornya, artinya semakin stabil kompleks ligan-reseptor tersebut. Pada Tabel 1 menunjukkan terdapat 18 ligan yang memiliki energi bebas lebih baik daripada native ligan dan senyawa induk yang menunjukkan bahwa senyawa tersebut memiliki afinitas ligan terhadap reseptor yang lebih baik dibanding native ligan dan senyawa induk serta lebih berpotensi sebagai anti-HIV dibanding native ligan sebagai pembanding. Energi bebas terendah ditunjukkan oleh ligan dengan substituen $\mathrm{CH}_{2}$-siklo- $\mathrm{C}_{3} \mathrm{H}_{5}$ pada posisi 1 dan 4 yaitu $-12.5798 \mathrm{kkal} / \mathrm{mol}$.

Interaksi antara ligan dengan residuresidu asam amino pada reseptor diantaranya melalui ikatan hidrogen intermolekular yaitu ikatan hidrogen yang terjadi antara senyawa turunan kuwanon- $\mathrm{H}$ dengan residu asam amino dari reseptor. Senyawa 4-chloro-8-methyl-7-(3methyl-but-2-enyl)-6,7,8,9-tetrahydro-2h2,7,9a-tri-aza-benzo[cd]azulene-1-thione (TB9) dengan reseptor $H I V-1 R T$ tidak terjadi ikatan hidrogen dan residu asam amino yang berinteraksi pada ikatan ligan reseptor sebanyak 8 residu. Interaksi antara senyawa induk kuwanon-H dengan reseptor HIV-1 RT yaitu terjadi ikatan hidrogen diantara atom $\mathrm{O}(8)$ dengan Arg A172 dimana jarak keduanya $2.9003 \AA$ Å sedangkan residu asam amino yang berinteraksi pada ikatan ligan reseptor sebanyak 13 residu. Untuk senyawa turunan kuwanon-H terbaik juga berinteraksi dengan reseptor $H I V-I$ $R T$ dan terjadi delapan ikatan hidrogen yaitu diantara atom $\mathrm{O}(8)$ dengan Lys A101, Thr B675, Ser B670, Glu B674, Thr B675, Thr B675, Glu B564, dan Lys B568. Sedangkan residu asam amino yang berinteraksi pada ikatan ligan reseptor sebanyak 18 residu.

Tabel 1. Data energi bebas senyawa desain

\begin{tabular}{|c|c|c|c|c|}
\hline \multirow{2}{*}{ Kode Substituen } & \multirow{2}{*}{ Substituen } & \multicolumn{3}{|c|}{ Energi bebas $(\Delta \mathbf{G})(\mathrm{kkal} / \mathrm{mol})$} \\
\hline & & Posisi $\mathrm{X}_{1}$ & Posisi $\mathrm{X}_{4}$ & Posisi $X_{1}$ dan $X_{4}$ \\
\hline- & TB9 & -11.0445 & -11.0445 & -11.0445 \\
\hline- & Senyawa induk & -11.0189 & -11.0189 & -11.0189 \\
\hline 1 & i- $\mathrm{C}_{3} \mathrm{H}_{7}$ & -10.0014 & -10.9701 & -11.289 \\
\hline 2 & siklo- $\mathrm{C}_{5} \mathrm{H}_{9}$ & -9.70644 & -8.34525 & -8.7438 \\
\hline 3 & siklo- $\mathrm{C}_{6} \mathrm{H}_{11}$ & -10.1076 & -10.9745 & -10.8431 \\
\hline 4 & $\mathrm{CH}_{2} \mathrm{C}_{6} \mathrm{H}_{5}$ & -11.1571 & -8.74602 & -9.6529 \\
\hline 5 & $\left(\mathrm{CH}_{2}\right)_{2}-\mathrm{C}_{6} \mathrm{H}_{5}$ & -10.2943 & -12.2223 & -12.42 \\
\hline 6 & siklo- $\mathrm{C}_{4} \mathrm{H}_{7}$ & -9.69428 & -11.7986 & -10.8399 \\
\hline 7 & $\mathrm{CH}_{2}$-siklo- $\mathrm{C}_{3} \mathrm{H}_{5}$ & -9.06539 & -11.9138 & -12.5798 \\
\hline 8 & $\mathrm{t}-\mathrm{C}_{4} \mathrm{H}_{9}$ & -9.12259 & -10.2455 & -11.3334 \\
\hline 9 & $\mathrm{C}_{2} \mathrm{H}_{5}$ & -11.3971 & -10.4101 & -9.61754 \\
\hline 10 & $\mathrm{CHCl}_{2}$ & -11.3608 & -11.3207 & -11.8471 \\
\hline 11 & $\mathrm{CF}_{3}$ & -10.4187 & -10.6217 & -10.5337 \\
\hline 12 & $\mathrm{CH}_{2}-\mathrm{CF}_{3}$ & -11.8376 & -11.4353 & -9.8297 \\
\hline 13 & $\mathrm{CH}_{2}-\mathrm{SCH}_{3}$ & -11.7566 & -11.4173 & -10.2462 \\
\hline 14 & $\mathrm{C}_{6} \mathrm{H}_{5}$ & -10.0422 & -11.2908 & -10.5239 \\
\hline 15 & $\mathrm{H}$ & -10.9628 & -9.68545 & -9.68545 \\
\hline 16 & $\mathrm{CH}_{2}-\mathrm{OH}$ & -11.1955 & -9.73485 & -9.70412 \\
\hline 17 & $\left(\mathrm{CH}_{2}\right)_{2}-\mathrm{OH}$ & -7.15892 & -8.3595 & -8.96254 \\
\hline 18 & $\mathrm{CH}_{2}-\mathrm{OCH}_{3}$ & -9.33541 & -8.3764 & -9.33541 \\
\hline 19 & $\left(\mathrm{CH}_{2}\right)_{2}-\mathrm{OCH}_{3}$ & -9.42104 & -8.76046 & -9.56441 \\
\hline 20 & $\mathrm{CH}_{2}-\mathrm{SO}_{2} \mathrm{CH}_{3}$ & -8.85123 & -10.7487 & -9.69612 \\
\hline
\end{tabular}


Tabel 2. Interaksi ligan (energi bebasnya lebih rendah dari native ligan maupun senyawa induk) dengan residu asam amino dari reseptor $H I V-1$ RT (1REV)

\begin{tabular}{|c|c|c|c|}
\hline Ligan & Kontak Residu & $\begin{array}{l}\text { Ikatan } \\
\text { Hidrogen }\end{array}$ & Jarak ikatan $(\AA)$ \\
\hline Native & Lys A101, Leu A100, Tyr A181, Tyr A188, Trp A229, & - & - \\
\hline ligan & Val A106, His A235 dan Phe A227 & & \\
\hline Senyawa & Arg A172, Thr A165, Ile B678, Lys B585, Gly B677, Ser & Arg A172(O) & 2.9003 \\
\hline induk & $\begin{array}{l}\text { B670, Lys B568, Pro B669, Ile B671, Ile B567, Glu B572, } \\
\text { Glu B564, Val B571 }\end{array}$ & & \\
\hline \multirow[t]{2}{*}{ K1-4 } & Pro 243, Gln 242, Leu 228, Tyr 183, Asp 185, Tyr 188, & Leu A228(O) & 2.03244 \\
\hline & Trp 229, Met 184, Lys 223 & Tyr A183(O) & 3.07649 \\
\hline \multirow[t]{2}{*}{ K1-9 } & Arg A172, Val B571, Glu B572, Ile B567, Glu B564, Ile & Arg A172(O) & 2.88113 \\
\hline & $\begin{array}{l}\text { B671, Pro B669, Lys B568, Ser B670, Ile B678, Lys } \\
\text { B585, Gly B677, Thr A165 }\end{array}$ & Pro B669(O) & 3.59725 \\
\hline \multirow[t]{4}{*}{$\mathrm{K} 1-10$} & Glu A169, Lys B585, Thr B675, Ile B668, Lys B568, Ile & Glu A169(O) & 2.34501 \\
\hline & B671, Glu B564, Ser B670, Pro B669, Ile B567, Ile B678, & Lys B585(O) & 2.82837 \\
\hline & Val B571 & Thr B675(O) & 2.59473 \\
\hline & & Ile $6 \mathrm{~B} 71(\mathrm{O})$ & 2.87685 \\
\hline \multirow[t]{2}{*}{$\mathrm{K} 1-12$} & Arg A172, Lys B585, Val B571, Ile B567, Glu B564, Ile & $\operatorname{Arg} \mathrm{A} 172(\mathrm{O})$ & 3.47099 \\
\hline & B564, Ser B670, Lys B568, Pro B669, Ile B678, Gly B677 & & \\
\hline \multirow[t]{8}{*}{ K1-13 } & Ile B671, Glu B674, Ser B670, Thr B675, Pro B669, Pro & Lys A101(O) & 3.40191 \\
\hline & B676, Gly B677, Ile B668, Ile B678, Val B571, Ala B569, & Thr B675(O) & 2.32587 \\
\hline & Ile B567, Lys B568, Trp A383, Glu B564, Lue A100, Pro & Ser B670(O) & 3.15443 \\
\hline & A321, Lys A101, Tyr A319 & Glu B674(O) & 3.33555 \\
\hline & & Thr B675(O) & 3.36754 \\
\hline & & Thr B675(O) & 2.99145 \\
\hline & & Glu B564(O) & 2.89952 \\
\hline & & Lys B568(O) & 3.09353 \\
\hline $\mathrm{K} 1-16$ & $\begin{array}{l}\text { Arg A172, Thr A165, Gly B677, Arg B679, Lys B585, Ile } \\
\text { B678, Pro B669, Val B571, Ile B671, Ile B567, Ser B670, } \\
\text { Lys B568, Glu B564 }\end{array}$ & Pro B669(O) & 2.89999 \\
\hline K4-5 & $\begin{array}{l}\text { Phe } 87 \text {, Lys } 154 \text {, Glu 89,Val 90, Tyr 115, Gln 151, Met } \\
\text { 184, Tyr 183, Asp } 185\end{array}$ & Lys A154 (O) & 2.89287 \\
\hline \multirow[t]{2}{*}{ K4-6 } & Val B571, Pro B669, Ile B678, Ile B567, Lys B568, Glu & Glu B564 (O) & 3.10329 \\
\hline & $\begin{array}{l}\text { B564, Ile B671, Ile 668, Thr B675, Ser B670, Glu A169, } \\
\text { Pro A170, Lys A173 }\end{array}$ & Ile B671 (O) & 2.89174 \\
\hline K4-7 & $\begin{array}{l}\text { Arg A172, Gly B677, Thr A165, Arg B679, Lys B585, } \\
\text { Pro B669, Ile B678, Glu B564, Ser B670, Ile B567, Ile } \\
\text { B671, Lys B568, Val B571 }\end{array}$ & Pro B669 (O) & 2.89911 \\
\hline \multirow[t]{4}{*}{ K4-10 } & Ile B567, Pro B669, Ser B670, Val B571, Ile B671, Thr & Glu A169 (O) & 2.7728 \\
\hline & B675, Ile B678, Lys B585, Thr A165, Lys A173, Glu & Lys B585 (O) & 2.97952 \\
\hline & A169, Pro A170 & Thr B675 (O) & 2.89787 \\
\hline & & Ile B671 (O) & 3.48443 \\
\hline \multirow[t]{3}{*}{ K4-12 } & Lys B585, Val B571, Glu B564, Ile B567, Pro B669, Ile & Pro B669 (O) & 2.90007 \\
\hline & B671, Ile B678, Ser B670, Thr A165, Gly B677, Arg & & \\
\hline & B679, Glu A169, Lys B585, Arg A172 & & \\
\hline \multirow[t]{3}{*}{ K4-13 } & Val B571, Arg B679, Gly B677, Ile B668, Pro B669, Ile & Thr B675 (O) & 3.28332 \\
\hline & B671, Ile B567, Ile B678, Ser B670, Val A179, Thr B675, & Thr B675 (O) & 2.90603 \\
\hline & Arg A172, Lys B585 & Lys B585 (O) & 3.32865 \\
\hline K4-14 & $\begin{array}{l}\text { Thr B675, Val B571, Lys B568, Pro B669, Glu B564, Ile } \\
\text { B567, Ser B670, Ile B671, Ile B678, Lys B585, Gly B677, } \\
\text { Thr A165 }\end{array}$ & Thr B675 (O) & 2.89938 \\
\hline \multirow[t]{5}{*}{ K14-1 } & Val A381, Ser B670, Asn B673, Asn B672, Ile A380, Ile & Leu A92(O) & 3.09303 \\
\hline & A94, Pro B561, Met A230, Trp A266, Tyr A232, Leu & Ile A94(O) & 3.09367 \\
\hline & A92, Glu A378, Thr A377 & Val A381(O) & 2.86115 \\
\hline & & Asn B672(O) & 3.39549 \\
\hline & & Asn B673(O) & 3.37408 \\
\hline \multirow[t]{4}{*}{ K14-5 } & Ile B567, Lys B568, Val B571, Ile B671, Glu B674, Val & Lys A101 (O) & 3.50083 \\
\hline & A179, Lys A101, Lys A103, Lys A102, Leu A193, Ser & Lys A103 (O) & 3.29927 \\
\hline & A191, Arg A192, Asp A177 & Ile B671 (O) & 3.21151 \\
\hline & & Glu B674 (O) & 2.44487 \\
\hline \multirow[t]{6}{*}{ K14-7 } & Leu A100, Lys A101, Tyr A319, Ser B670, Glu B674, Ile & Lys A101(O) & 3.46608 \\
\hline & B678, Pro B669, Thr B675, Gly B677, Ile B668, Val & Thr B675(O) & 2.31257 \\
\hline & B571, Ile B567, Lys B568, Glu B564, Ala B569, Ile B671, & Ser B670(O) & 3.22883 \\
\hline & Trp A383, Pro A321 & Glu B674(O) & 3.43008 \\
\hline & & Thr B675(O) & 3.36311 \\
\hline & & Thr B675(O) & 2.90568 \\
\hline
\end{tabular}




\begin{tabular}{|c|c|c|c|}
\hline & & $\begin{array}{l}\text { Glu B564(O) } \\
\text { Lys B568(O) }\end{array}$ & $\begin{array}{c}2.84749 \\
3.0566\end{array}$ \\
\hline K14-8 & $\begin{array}{l}\text { Ile B567, Ser B670, Glu B674, Lys B568, Val B571, Ile } \\
\text { B678, Thr B675, Pro B669, Glu A169, Ile B668, Lys } \\
\text { B585, Arg A172, Ile B571 }\end{array}$ & Thr B675 (O) & 2.90311 \\
\hline K14-10 & $\begin{array}{l}\text { Val B571, Glu B572, Glu B564, Ile B567, Ile B671, Pro } \\
\text { B669, Lys B68, Ile B678, Ser B760, Lys B585, Arg B679, } \\
\text { Gly B677, Thr A165, Arg A172 }\end{array}$ & $\begin{array}{l}\text { Arg A172 }(\mathrm{O}) \\
\text { Pro B669 (O) }\end{array}$ & $\begin{array}{l}2.89986 \\
3.47699\end{array}$ \\
\hline
\end{tabular}

Keterangan : $\mathrm{K}=$ Kuwanon $; 1=$ Modifikasi pada posisi $\mathrm{X}_{1}$; 4 = Modifikasi pada posisi $\mathrm{X}_{4} ; 1-20=$ Substituen

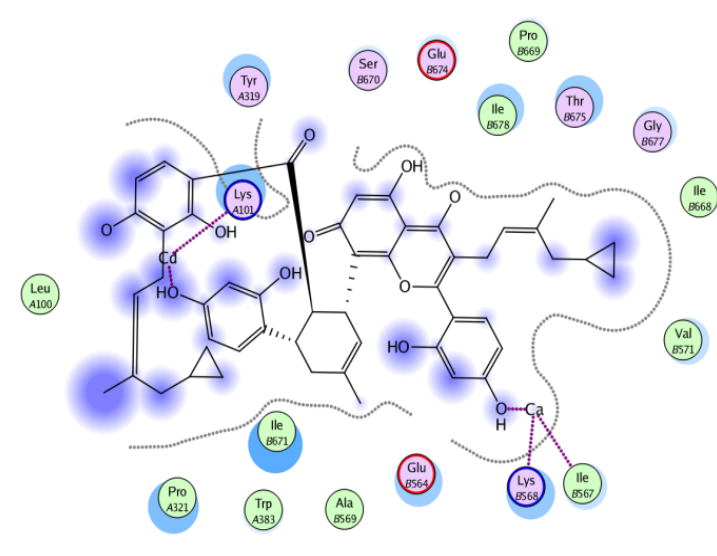

(a)

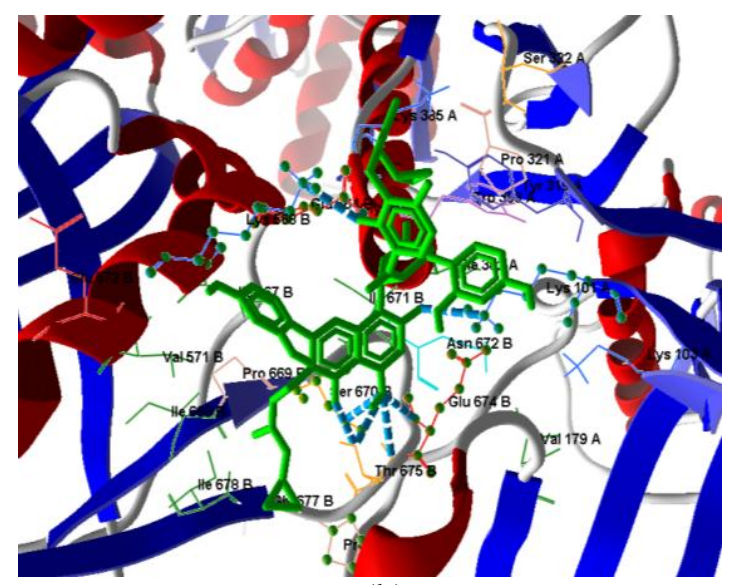

(b)

Gambar 6. (a) Visualisasi 2D interaksi penambatan pada senyawa terbaik (substitusi $\mathrm{CH}_{2}$-siklo- $\mathrm{C}_{3} \mathrm{H}_{5}$ pada posisi 1 dan 4) dengan reseptor HIV-1 RT (1REV) menggunakan Molecular Operating Environment; (b) Visusalisasi 3D interaksi penambatan pada senyawa terbaik (substitusi $\mathrm{CH}_{2}$-siklo- $\mathrm{C}_{3} \mathrm{H}_{5}$ pada posisi 1 dan 4) dengan reseptor HIV-1 RT (1REV) menggunakan Molegro Molecular Viewer

\section{Penerapan Aturan Lipinski}

Senyawa dikatakan memiliki absorpsi atau permeabilitas tinggi apabila memenuhi 2 atau lebih kriteria di bawah ini (Athar et al., 2017; Choy et al., 2011); bobot molekul tidak lebih dari 500, koefisien partisi oktanol/air (Log P) terhitung kurang dari 5 , donor ikatan hidrogen tidak lebih dari 5, akseptor ikatan hidrogen tidak lebih dari 10 dan refraktivitas molar diantara 40130.

Hasil penapisan yang dapat dilihat pada Tabel 3 menunjukkan bahwa senyawa-senyawa turunan kuwanon- $\mathrm{H}$ terbaik tidak memenuhi aturan Lipinski dalam semua parameter yang digunakan. Hal ini menunjukkan bahwa semua senyawa turunan kuwanon-H tidak memiliki profil seperti drug likeness yang diharapkan. Artinya dengan adanya modifikasi struktur tidak mengubah profil dari senyawa tersebut.

\section{Hasil Prediksi Toksisitas}

Uji toksisitas dilakukan dengan menggunakan aplikasi Toxtree terhadap semua senyawa turunan kuwanon-H yang memiliki energi lebih rendah dari native ligan dan hasil uji toksisitasnya dapat dilihat pada Tabel 4. Menurut parameter Cramer Rules, semua senyawa turunan kuwanon-H termasuk ke dalam kategori tiga yaitu toksisitas tinggi (High Class). Hal ini menunjukkan bahwa senyawa turunan kuwanon$\mathrm{H}$ termasuk senyawa dengan struktur kimia yang dianggap tidak terjamin keamanannya atau memungkinkan terjadi toksisitas yang signifikan atau mempunyai gugus fungsional yang reaktif.

Menurut parameter Benigni/Bossa rulebase, semua senyawa turunan kuwanon- $\mathrm{H}$ kecuali senyawa dengan substituen $\mathrm{CHCl}_{2}$ tidak bersifat karsinogenik karena hasil pengamatan menunjukkan negatif terhadap genotoksik maupun nongenotoksik karsinogenik. Sedangkan resiko mutagenisitas tidak ditunjukkan oleh parameter ini. Untuk senyawa dengan substitusen $\mathrm{CHCl}_{2}$ menunjukkan positif terhadap genotoksik karsinogenik. Selain itu, menurut parameter Kroes TTC decision tree, semua senyawa turunan kuwanon-H kecuali senyawa dengan substituen $\mathrm{CHCl}_{2}$ termasuk kategori 1 yaitu senyawa diduga tidak aman dan memiliki resiko bagi kesehatan. 
Sedangkan senyawa turunan dengan substituen $\mathrm{CHCl}_{2}$ termasuk kategori 2 yaitu menunjukkan bahwa resiko toksisitas dari senyawa dapat diabaikan.

Tabel 3. Hasil penapisan menurut aturan lipinski

\begin{tabular}{|c|c|c|c|c|c|}
\hline Ligan & Berat Molekul & $\log P$ & $\begin{array}{l}\text { Donor Ikatan } \\
\text { Hidrogen }\end{array}$ & $\begin{array}{l}\text { Akseptor Ikatan } \\
\text { Hidrogen }\end{array}$ & $\begin{array}{l}\text { Refraktivitas } \\
\text { Molar }\end{array}$ \\
\hline Senyawa induk & 760.288 & 9.57 & 8 & 11 & 216.91 \\
\hline $\mathrm{K} 1-4$ & 836.9202 & 11.15 & 8 & 11 & 241.61 \\
\hline K1-9 & 774.8508 & 10.02 & 8 & 11 & 221.51 \\
\hline K1-10 & 829.714 & 10.31 & 8 & 13 & 226.79 \\
\hline $\mathrm{K} 1-12$ & 828.8222 & 10.21 & 8 & 14 & 222.30 \\
\hline K1-13 & 806.916 & 9.93 & 8 & 11 & 229.37 \\
\hline K1-16 & 776.8237 & 8.29 & 9 & 12 & 218.69 \\
\hline $\mathrm{K} 4-5$ & 850.9468 & 11.60 & 8 & 11 & 246.21 \\
\hline K4-6 & 800.8881 & 10.28 & 8 & 11 & 228.86 \\
\hline $\mathrm{K} 4-7$ & 800.8881 & 10.28 & 8 & 11 & 228.86 \\
\hline K4-10 & 829.714 & 10.31 & 8 & 13 & 226.79 \\
\hline K4-12 & 828.8222 & 10.21 & 8 & 14 & 222.30 \\
\hline K4-13 & 806.916 & 9.93 & 8 & 11 & 229.37 \\
\hline K4-14 & 822.8936 & 10.84 & 8 & 11 & 237.01 \\
\hline K14-1 & 816.9306 & 11.04 & 8 & 11 & 235.21 \\
\hline K14-5 & 941.0693 & 13.62 & 8 & 11 & 275.50 \\
\hline K14-7 & 840.9520 & 11.00 & 8 & 11 & 240.81 \\
\hline K14-8 & 844.9837 & 11.64 & 8 & 11 & 244.16 \\
\hline K14-10 & 898.604 & 11.06 & 8 & 15 & 236.67 \\
\hline
\end{tabular}

Tabel 4. Hasil prediksi toksisitas toxtree

\begin{tabular}{|c|c|c|c|c|}
\hline \multirow[b]{2}{*}{ Ligan } & \multirow[b]{2}{*}{ Substituen } & \multicolumn{3}{|c|}{ Parameter } \\
\hline & & Cramer Rules & Benigni/Bosa Rulebase & Kroes TTC Decision tree \\
\hline K1-4 & $\mathrm{CH}_{2} \mathrm{C}_{6} \mathrm{H}_{5}$ & 3 & 8.9 & 1 \\
\hline K1-9 & $\mathrm{C}_{2} \mathrm{H}_{5}$ & 3 & 8.9 & 1 \\
\hline $\mathrm{K} 1-10$ & $\mathrm{CHCl}_{2}$ & 3 & 1.9 & 2 \\
\hline K1-12 & $\mathrm{CH}_{2}-\mathrm{CF}_{3}$ & 3 & 8.9 & 1 \\
\hline K1-13 & $\mathrm{CH}_{2}-\mathrm{SCH}_{3}$ & 3 & 8.9 & 1 \\
\hline K1-16 & $\mathrm{CH}_{2}-\mathrm{OH}$ & 3 & 8.9 & 1 \\
\hline K4-5 & $\left(\mathrm{CH}_{2}\right)_{2}-\mathrm{C}_{6} \mathrm{H}_{5}$ & 3 & 8.9 & 1 \\
\hline K4-6 & siklo- $\mathrm{C}_{4} \mathrm{H}_{7}$ & 3 & 8.9 & 1 \\
\hline K4-7 & $\mathrm{CH}_{2}$-siklo- $\mathrm{C}_{3} \mathrm{H}_{5}$ & 3 & 8.9 & 1 \\
\hline K4-10 & $\mathrm{CHCl}_{2}$ & 3 & 1.9 & 2 \\
\hline K4-12 & $\mathrm{CH}_{2}-\mathrm{CF}_{3}$ & 3 & 8.9 & 1 \\
\hline K4-13 & $\mathrm{CH}_{2}-\mathrm{SCH}_{3}$ & 3 & 8.9 & 1 \\
\hline K4-14 & $\mathrm{C}_{6} \mathrm{H}_{5}$ & 3 & 8.9 & 1 \\
\hline K14-1 & i- $\mathrm{C}_{3} \mathrm{H}_{7}$ & 3 & 8.9 & 1 \\
\hline K14-5 & $\left(\mathrm{CH}_{2}\right)_{2}-\mathrm{C}_{6} \mathrm{H}_{5}$ & 3 & 8.9 & 1 \\
\hline K14-7 & $\mathrm{CH}_{2}$-siklo- $\mathrm{C}_{3} \mathrm{H}_{5}$ & 3 & 8.9 & 1 \\
\hline K14-8 & $\mathrm{t}-\mathrm{C}_{4} \mathrm{H}_{9}$ & 3 & 8.9 & 1 \\
\hline K14-10 & $\mathrm{CHCl}_{2}$ & 3 & 1.9 & 2 \\
\hline \multicolumn{5}{|l|}{ Keterangan : } \\
\hline Cramer rule: & & \multicolumn{3}{|c|}{$=3(\operatorname{High}($ Class 3$))$} \\
\hline \multicolumn{2}{|c|}{ Benigni/Bosa rulebase } & \multicolumn{3}{|c|}{$\begin{aligned}= & 1 \text { (Structural alerts for genotoxic carcinogenicity); } 8 \text { (Negatif for genotoxic } \\
& \text { carcinogenicity); } 9 \text { (Negatif for nongenotoxic carcinogenicity) }\end{aligned}$} \\
\hline \multicolumn{2}{|c|}{ Kroes TTC decision tree } & \multicolumn{3}{|c|}{$\begin{aligned}= & 1(\text { Substance would not expected to be safety concern }) ; 2(\text { Negligible risk (low } \\
& \left.\left.\text { probability of a life-time cancer riskgreater than } 1 \text { in } 10^{6}\right)\right)\end{aligned}$} \\
\hline
\end{tabular}




\section{SIMPULAN}

Berdasarkan hasil penambatan dapat disimpulkan bahwa senyawa turunan kuwanon secara in silico mampu berinteraksi dengan reseptor HIV-1 Reverse Transcriptase (1REV) dan senyawa yang terbaik adalah senyawa turunan kuwanon-H yang dimodifikasi pada posisi 1 dan 4 (substituen $\mathrm{CH}_{2}$-siklo- $\mathrm{CH}_{3}$ ) dengan nilai energi bebas yaitu -12.5798 $\mathrm{kkal} / \mathrm{mol}$. Kemudian berdasarkan uji toksisitas menunjukkan bahwa semua senyawa uji terkecuali senyawa dengan substituent $\mathrm{CHCl}_{2}$ cukup berpotensi menimbulkan toksisitas tetapi tidak berpotensi menimbulkan efek karsinogenik atau mutagenik.

\section{DAFTAR PUSTAKA}

Athar M, Lone MY, Jha PC. 2017. First protein drug target's appraisal of lead-likeness descriptors to unfold the intervening chemical space. Journal of Molecular Graphics and Modelling. 72: 272-282.

Benigni R, Bossa C. 2008. The benigni/bossa rulebase for mutagenicity and carcinogenicity a module of toxtree. JRC Scientific and Technical Reports. European Comission Joint Research Center.

Bhhatarai B, Wilson DM, Parks AK, Carney EW, Spencer PJ. 2016. Evaluation of TOPKAT, toxtree, and derek nexus in silico models for ocular irritation and development of a knowledge-based framework to improve the prediction of severe irritation. Chemical Research in Toxicology. 29.

Bhatia S, Schultz T, Roberts D, Shen J, Kromidas L, Marie AA. 2015. Comparison of cramer classification between toxtree, the OECD QSAR toolbox and expert judgment. Regulatory Toxicology and Pharmacology. 71(1): 52-62.

Callies O, Bedoya LM, Beltrán M, Muñoz A, Calderón PO, Osorio AA, Jimenez IA, Alcami J, Bazzocchi IL. (2015). Isolation, structural modification, and HIV inhibition of pentacyclic lupane-type triterpenoids from Cassine xylocarpa and Maytenus cuzcoina. Journal of Natural Products. 78(5): 10451055.

Choy Y, Bin, Prausnitz MR. 2011. The rule of five for non-oral routes of drug delivery: ophthalmic, inhalation, and transdermal. Pharmaceutical Research. 28(5): 943-948.
Contrera JF. 2013. Validation of toxtree and SciQSAR in silico predictive software using a publicly available benchmark mutagenicity database and their applicability for the qualification of impurities in pharmaceuticals. Regulatory Toxicology and Pharmacology. 67(2): 285-293.

Ekins S, Mestres J, Testa B. 2002. In silico pharmacology for drug discovery: application to targets and beyond. British Journal of Pharmacology Review. 152: 21-37.

Feng XQ, Liang YH, Zeng Z, Sen, Chen FE, Balzarini J, Pannecouque C, De Clercq E. 2009. Structural modifications of DAPY analogues with potent anti-HIV-1 activity. ChemMedChem. 4(2): 219-224.

Firdayani. 2012. Pengembangan Kandidat Senyawa Obat Turunan Naftokuinon Sebagai Inhibitor Virus Hepatitis B. Prosiding InSINas : 35-39.

Gu SX, Zhu YY, Chen FE, De Clercq E, Balzarini J, Pannecouque C. 2015. Structural modification of diarylpyrimidine derivatives as HIV-1 reverse transcriptase inhibitors. Medicinal Chemistry Research. 24(1).

Hafeez A, Saify ZS, Naz A, Yasmin F, Akhtar N. 2013. Molecular penambatan study on the interaction of riboflavin (vitamin B2) and cyanocobalamin (vitamin B12) coenzymes. Journal of Computational Medicine. 2013: 15.

http://www.who.int/hiv/en/. [diakses 25 Maret 2018].

http://www.who.int/mediacentre/factsheets/fs360/en/ . [diakses 25 Maret 2018].

Imai K, Ochiai K. 2011. Role of histone modification on transcriptional regulation and HIV-1 gene expression: possible mechanisms of periodontal diseases in AIDS progression. Journal of Oral Science. 53(1): 1-13.

Kancev, Angel. 2009. Toxtree User Manual, Bulgaria: Idea Consult Ltd.

Kartasasmita RE, Herowati R, Harmastuti N, Gusdinar T. 2009. Quercetin derivatives penambatan based on study of flavonoids interaction to cyclooxygenase- 2 penambatan turunan kuersetin berdasarkan studi interaksi flavonoid terhadap enzim. Indo. J.chem. 9(2): 297-302. 
Nursalam, Kurniawati ND. 2009. Asuhan Keperawatan pada Pasien Terinfeksi HIV/AIDS. Jakarta (ID): Salemba Medika.

Parikesit AA, Nurdiansyah R, Agustriawan D. 2018. Telaah sistematis terhadap basis data bahan alam untuk pengembangan produk suplemen herbal. Pros. SEMNASTAN 0:62-68. [accessed 2018 Jan 28].

Patlewicz G, Jeliazkova N, Safford RJ, Worth AP, Aleksiev B. 2008. An evaluation of the implementation of the Cramer classification scheme in the Toxtree software. SAR and QSAR in Environmental Research. 19(5-6): 495-524.

Ren J, Esnouf R, Hopkins A, Ross C, Jones Y, Stammers D, Stuart D. 1995. The structure of HIV-1 reverse transcriptase complexed with 9-chloro-TIBO: lessons for inhibitor design. Structure. 3(9): 915-926.

Ruswanto. 2015. Molekular docking empat turunan isonicotinohydrazide pada Mycobacterium tuberculosis enoyl-acyl carrier reductase (InhA). Jurnal Kesehatan Bakti Tunas Husada. 13: 213-227.

Ruswanto, Siswandono, Richa M, Tita N, Tresna L. 2017. Molecular penambatan of 1-benzoyl-3methylthiourea as anti cancer candidate and its absorption, distribution, and toxicity prediction. J. Pharm. Sci. \& Res. 9(5): 680684.

Shi D, Nemec J, Bing M, Ning. 1995. Anti HIV flavonoid from Morus alba. Acta Botanica Yunnanica. 17: 89-95.

Stephen, Gilman AG. 2012. Dasar Farmakologi Terapi, edisi 10 volume 3. Jakarta (ID): :EGC.
Syahdi RR, Mumin A, Suhartanto H, Yanuar A. 2012. Virtual screening of indonesian herbal database as HIV-1 reverse trancriptase inhibitor. Biomedical Informatics. 8: 12061210.

Tambunan USF, Harganingtyas R, Harganingt R, Parikesit AA. 2012. In silico modification of (1R, 2R, 3R, 5S)-(-)- isopinocampheylamine as inhibitors of $\mathrm{M} 2$ proton channel in influenza a virus subtype H1N1, using the molecular docking approach. Trends Bioinforma. 5: 25-46.

Tambunan USF, Amri N, Parikesit AA. 2012. In silico design of cyclic peptide as influenza virus, a subtype H1N1 neuraminidase inhibitor. African Journal of Biotechnology 11(52): p11474-11491.

Thompson M. 2004. ArgusLab 4.0.1, Planaria Software LLC., Seatle, Wash, USA.

Vijayakumar R, Senbagam R, Rajarajan M, Manikandan V, Balaji S, Vanangamudi G, Thirunarayanan G. 2017. Synthesis, study of structure activity relationship and evaluation of biological activities of substituted ( E )-2benzylidene$\mathrm{N}$ methylhyrazinecarbothioamides. 12(4): 130 137.

Zukhrullah, Mukhtasyam, Aswad M, Subehan. 2012. Kajian beberapa Senyawa antiinflamasi: penambatan terhadap siklooksigenase-2 secara in silico. Majalah Farmasi dan Farmakologi. 16: 37-44. 